Johnson \& Wales University

ScholarsArchive@JWU

College of Business Faculty Publications and Research

Spring 4-2020

\title{
Reconceptualizing the Hierarchical Service Quality Model: The Case of Agritourism Events
}

\author{
Rebecca Liang Tang \\ Jessica Hurst \\ Linda Niehm \\ Anne-Marie Fiore \\ Amy Dorie
}

See next page for additional authors

Follow this and additional works at: https://scholarsarchive.jwu.edu/mgmt_fac

Part of the Tourism and Travel Commons

\section{Repository Citation}

Tang, Rebecca Liang; Hurst, Jessica; Niehm, Linda; Fiore, Anne-Marie; Dorie, Amy; and Jablon-Roberts, Sara, "Reconceptualizing the Hierarchical Service Quality Model: The Case of Agritourism Events" (2020). College of Business Faculty Publications and Research. 2.

https://scholarsarchive.jwu.edu/mgmt_fac/2

This Article is brought to you for free and open access by the College of Business at ScholarsArchive@JWU. It has been accepted for inclusion in College of Business Faculty Publications and Research by an authorized administrator of ScholarsArchive@JWU. For more information, please contact jcastel@jwu.edu. 


\section{Authors}

Rebecca Liang Tang, Jessica Hurst, Linda Niehm, Anne-Marie Fiore, Amy Dorie, and Sara Jablon-Roberts 


\title{
RECONCEPTUALIZING THE HIERARCHICAL SERVICE QUALITY MODEL: THE CASE OF AGRITOURISM EVENTS
}

\author{
LIANG (REBECCA) TANG, ${ }^{*}$ JESSICA HURST, ${ }^{*}$ LINDA NIEHM, ${ }^{*}$ ANN MARIE FIORE,* \\ AMY DORIE, $\dagger$ AND SARA JABLON-ROBERTS*
}

*Department of Apparel, Events, \& Hospitality Management, College of Human Sciences, Iowa State University, Ames, IA, USA

$\dagger$ Department of Family Interiors Nutrition \& Apparel, San Francisco State University, San Francisco, CA, USA †College of Business, Johnson \& Wales University, Providence, RI, USA

\begin{abstract}
To enhance the success of agritourism events and festivals, identified as important contributors to economic development in rural communities, this study investigated factors leading to revisit intentions toward these tourism activities. Taking an experience economy approach, the 4Es (educational, entertainment, escapist, and esthetic experiences) were used as alternative measures of outcome quality as part of a 4E-based reconceptualized hierarchical service quality model (HSQM). Data were collected from 529 respondents at three agritourism events in the state of Iowa. Structural equation modeling (SEM) revealed that overall service quality was comprised of all three dimensions of HSQM (interaction quality, physical environment quality, and outcome quality as indicated by the 4Es) and overall service quality was shown to be an antecedent of visitor satisfaction, which consequently led to revisit intention. Additionally, SEM results demonstrated the suitability of the hypothesized 4E-based HSQM model to explain the variance in overall service quality at agritourism events. Thus, this study provides an innovative theoretical foundation for future research investigating service quality, and suggests strategies that marketers can use to effectively enhance experiential offerings for visitors at agritourism events.
\end{abstract}

Key words: Agritourism; Events and festivals; Hierarchical service quality model (HSQM); 4Es; Experience economy

Introduction

Agritourism involves the activities developed in an agricultural environment for enjoyment or education concerning rural areas (Barbieri \& Mshenga,
2008; Marques, 2006). Events can provide a major platform for tourism development in agritourism destinations (Pema \& Custodio, 2008). Agritourism events are social gatherings that are usually short in duration (e.g., a weekend, one time, or semiyear)

Address correspondence to Liang (Rebecca) Tang, Ph.D., Associate Professor, Department of Apparel, Events, \& Hospitality Management, College of Human Sciences, Iowa State University, 31 MacKay Hall, 2302 Osborn Drive, Ames, IA 50011-1078, USA. Tel: (515) 294-8489; Fax: (515) 294-7474; E-mail: rebeccat@iastate.edu 
and relate to seasonal themes (e.g., fall harvest or spring tulip festival) in rural communities (Ramu \& Kathleen, 2014). Popular examples of agritourism events include corn mazes and pumpkin patches. Agritourism events offer visitors unique and authentic experiences associated with agricultural operations (e.g., farming and ranching). These events enhance understanding of food production and agricultural systems, and consequently, build public awareness of agriculture's contribution to economics and quality of life (Reid, 2011). Such venues also provide farmers and rural residents with a market to promote their agricultural and locally produced products (e.g., food and fiber, handicraft products, and artistic metalwork). Thus, agritourism events can generate supplemental income, diversify revenue streams for farms and rural businesses, and provide a buffer to the effects of agriculture market fluctuations (Kuehn, Hilchey, Ververs, Dunn, \& Lehman, 1998). Additionally, agritourism events enhance the image and visibility of rural communities, create temporary jobs for local residents, and generate funds to support community development (Chhabra, Sills, \& Cubbage, 2003; Govindasamy \& Kelley, 2014).

Given the benefits of agritourism events for rural communities, local agricultural producers, and visitors, it is crucial to understand the factors that contribute to the success of event planning. Wicks and Fesenmaier (1993) argued, "many factors may affect attendance at and profitability of special events, but catering to the customer's desires (service quality) is at the heart of developing a successful event-tourism product” (p. 19). Service quality is defined as a consumer's summative evaluation of the excellence or superiority of a service offered by a business (Bolton \& Drew, 1991). Service quality is a gauge of operational performance (Ko \& Patore, 2004), a determinant of an event's image and positioning (Martinez, Ko, \& Martinez, 2010), and an accelerator of profitability for the event provider (Dagger \& Sweeney, 2007). Service quality has also been shown to influence consumers' revisit behavior (e.g., Shonk \& Chelladurai, 2008; Zeithaml, Berry, \& Parasuraman, 1996). Repeat visitors are also a stable income source and cost less than attracting first-time attendees (Oppermann, 1997). Thus, service quality may play a critical role in attracting this important market segment of repeat visitors to agritourism events.
The hierarchical service quality model (HSQM) proposed by Brady and Cronin (2001) has been shown to be an effective tool in the assessment of service quality in hospitality and tourism contexts (e.g., Caro \& Garcia, 2008; Clemes, Brush, \& Collins, 2011). HSQM specifies that overall service quality is formed with three primary dimensions: interaction quality, physical environment quality, and outcome quality (Clemes, Gan, \& Ren, 2011; Lu, Zhang, \& Wang, 2009).

Outcome quality depicts a consumer's summative perception of his/her service experience, according to the Brady and Cronin model (2001). In their conceptualization of the original HSQM model, three subdimensions of outcome quality either capture a utilitarian perspective of consumer experience (e.g., wait time) or a general affective measure, including how good the experience was (valance) or how pleasing or likeable the experience was (tangibles). Whereas researchers (e.g., Clemes, Gan et al., 2011; Lu et al., 2009; Wu \& Cheng, 2013) have used this HSQM model successfully to determine service quality for service with a pragmatic focus (e.g., motel stays, sales of mobile phone service, airline industry), the hedonic/experiential nature of agritourism (Cetin \& Bilgihan, 2016; Quadri-Felitti, \& Fiore, 2012, 2013; Sznajder, Przezborska, \& Scrimgeour, 2009) supports the need for an HSQM outcome quality measure that captures hedonic/ experiential elements. Moreover, knowing that agritourism guests should have a good experience, be pleased by, and like the experience contributes little to understanding the nature of service quality as evaluated by the general affective measure of the original HSQM model (Brady \& Cronin, 2001). As such, this measure should be replaced with specific types of experiences relevant to agritourism events to better provide insight for agritourism operators. Therefore, we propose exchanging the utilitarian and general affective measure of the outcome quality (wait time, valence, and tangibles) with an experiential marketing measure, the 4Es (educational, entertainment, escapist, and esthetic experiences; Pine \& Gilmore, 1998), which has been found to be important in an array of tourism studies (see Table 1).

The purpose of the present study was twofold: 1) to propose a modified HSQM framework, which combines traditional service quality dimensions 
Table 1

Description of the 4Es, Hedonic Pleasure Dimensions, Examples of Agritourism Activities, and Tourism Literature Supporting the Importance of the 4E Realm and its Hedonic Dimensions

\begin{tabular}{|c|c|c|c|}
\hline $\begin{array}{l}\text { Description } \\
\text { (Fiore et al., 2007) }\end{array}$ & $\begin{array}{l}\text { Hedonic Dimensions } \\
\text { (Fiore et al., 2007) }\end{array}$ & $\begin{array}{l}\text { Agritourism Activity } \\
\text { Examples }\end{array}$ & $\begin{array}{l}\text { Supporting Tourism } \\
\text { Literature }\end{array}$ \\
\hline $\begin{array}{l}\text { Educational experience: } \\
\text { The tourist increases skills } \\
\text { and knowledge through } \\
\text { active engagement of the } \\
\text { mind and/or the body, } \\
\text { absorbing information in an } \\
\text { interactive manner }\end{array}$ & $\begin{array}{l}\text { Cognitive pleasure from } \\
\text { trying to master a challenge; } \\
\text { Emotional pleasure (joy, } \\
\text { contentment) from improv- } \\
\text { ing or mastering a challenge }\end{array}$ & $\begin{array}{l}\text { The tourist learns to distin- } \\
\text { guish between wines at } \\
\text { vineyard tasting or learns to } \\
\text { navigate a corn maze }\end{array}$ & $\begin{array}{l}\text { Cetin and Bilgihan (2014), } \\
\text { Mehmetoglu and Engen } \\
\text { (2011), Quadri-Felitti and } \\
\text { Fiore (2013), Richards and } \\
\text { Wilson (2006) }\end{array}$ \\
\hline $\begin{array}{l}\text { Entertainment experience: } \\
\text { The tourist perceives, but } \\
\text { is not actively part of, an } \\
\text { entertaining activity or } \\
\text { performance }\end{array}$ & $\begin{array}{l}\text { Cognitive pleasure from } \\
\text { observing an activity or } \\
\text { performance unfold to con- } \\
\text { clusion; Emotional pleasure } \\
\text { (fun, excitement, joy) from } \\
\text { observing an activity or } \\
\text { performance }\end{array}$ & $\begin{array}{l}\text { The tourist enjoys watching } \\
\text { staff compete in an apple } \\
\text { picking contest or watch- } \\
\text { ing chainsaw pole carving } \\
\text { demonstrations }\end{array}$ & $\begin{array}{l}\text { Hosany and Witham (2010), } \\
\text { Morgan et al. (2009) }\end{array}$ \\
\hline $\begin{array}{l}\text { Escapist experience: The } \\
\text { tourist shapes and par- } \\
\text { ticipates in an activity } \\
\text { contributing to a sense of a } \\
\text { different persona, time and/ } \\
\text { or place; this is more than } \\
\text { just getting away from daily } \\
\text { life or relieving boredom }\end{array}$ & $\begin{array}{l}\text { Cognitive pleasure from cre- } \\
\text { ating an alternative persona } \\
\text { or sense of different place } \\
\text { or time; Emotional pleasure } \\
\text { (fun, excitement, joy) from } \\
\text { partaking in the activity }\end{array}$ & $\begin{array}{l}\text { The dude ranch tourist moves } \\
\text { cattle with ranchers to sat- } \\
\text { isfy a sense of nostalgia for } \\
\text { the Old West }\end{array}$ & $\begin{array}{l}\text { Lee and Beeler (2009), } \\
\text { Mehmetoglu and Engen } \\
\text { (2011), Morgan et al. (2009) }\end{array}$ \\
\hline $\begin{array}{l}\text { Esthetic experience: The } \\
\text { tourist appreciates, but does } \\
\text { not measurably alter, an } \\
\text { enticing multisensory-rich } \\
\text { setting }\end{array}$ & $\begin{array}{l}\text { Sensual pleasure from enjoy- } \\
\text { ing an enticing setting; } \\
\text { Emotional pleasure (joy, } \\
\text { inner peace, awe) from } \\
\text { being immersed in an entic- } \\
\text { ing setting }\end{array}$ & $\begin{array}{l}\text { The tourist enjoys the sunset } \\
\text { over a vineyard or enjoys a } \\
\text { brilliant display of lit pump- } \\
\text { kin sculptures }\end{array}$ & $\begin{array}{l}\text { Oh et al. (2007), Quadri- } \\
\text { Felitti and Fiore (2013), } \\
\text { Hosany and Witham (2010) }\end{array}$ \\
\hline
\end{tabular}

with the 4Es as a measure of outcome quality, and 2 ) test the validity of the model's ability to predict the outcome variables (satisfaction and revisit intention) within the agritourism context (Fig. 1). Accordingly, three Iowa agritourism events were chosen at which to assess (a) perceptions of service quality (i.e., interaction quality, physical environment quality, and outcome quality), (b) the contributions of 4Es to form outcome quality, (c) the impact of service quality on visitor satisfaction, and (d) the consequent influence of visitor satisfaction on revisit intention.

Results of the current study may provide strategic guidance for agritourism event planners on how to improve service quality. In particular, understanding visitor perceptions of experiences at agritourism events would shed more light on visitor satisfaction, and possibly predict their likelihood of repeat visits. This information could be used by event planners to develop cost-effective marketing directives and strategies to promote repeat visits, which in turn could enhance revenue and increase profitability for agritourism event operators.

\section{Literature Review}

\section{Rural Economies and Agritourism}

The economies of contemporary rural areas are characterized by the development of large-scale farming operations, fewer small family farms, declines in manufacturing due to foreign competition, and technological change. These shifts have affected the employment base and also resulted in population declines, an older traditional resident profile, and an influx of newcomer populations in 


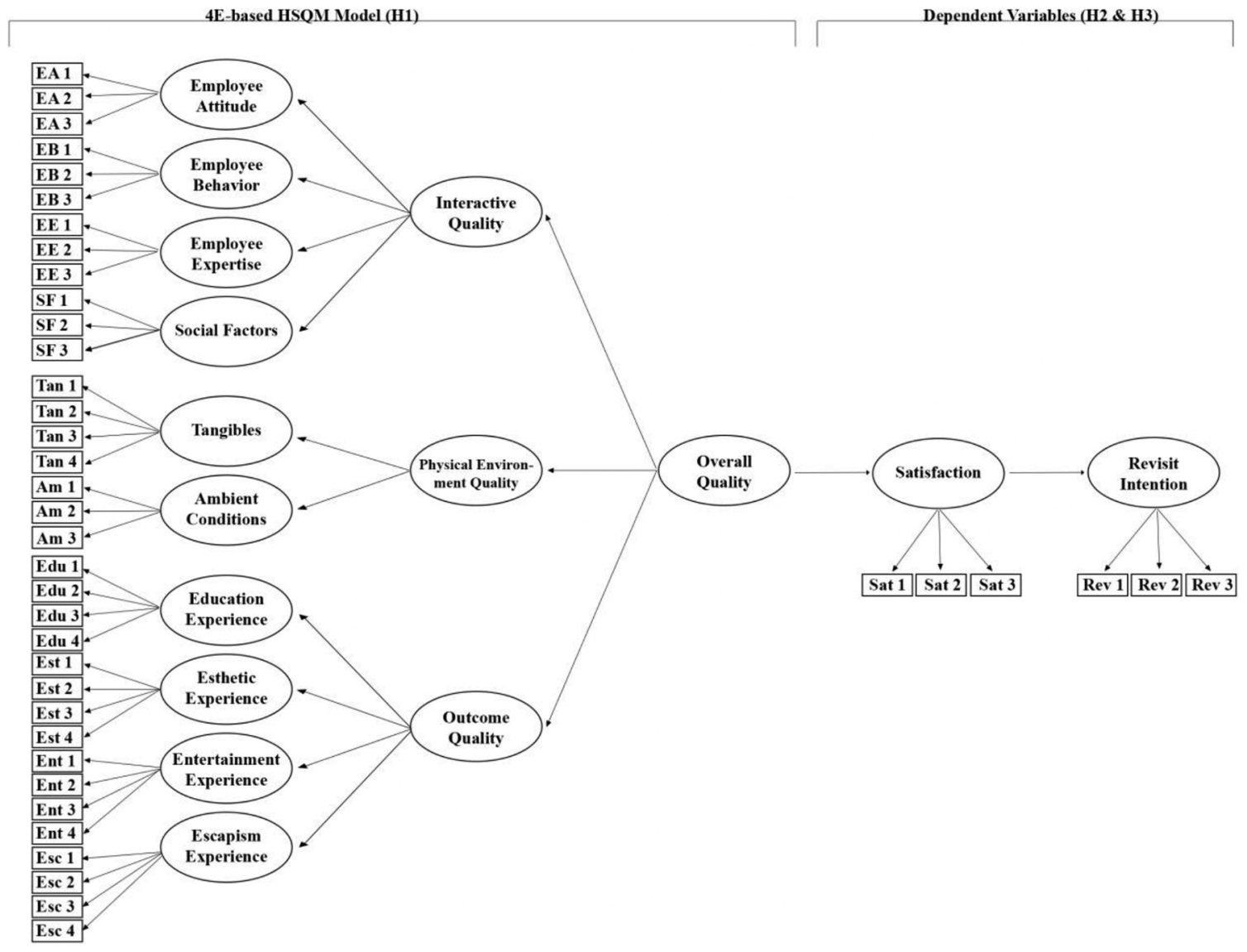

Figure 1. Reconceptualized 4E-based HSQM with hypothesized dependent variables.

some areas (Flora, 2018). Rural communities may also be differentially impacted by geographic location and access to natural resources and amenities (Brown \& Schafft, 2011; Leigh \& Blakely, 2016).

The economic recession of 2007-2009 created further economic challenges for rural communities and a heightened need to better understand alternative forms of economic activity for these areas (Niehm, Fitzgerald, \& Muske, 2017). Traditional types of rural businesses have experienced limited growth since the recession, and small communities have necessarily sought other drivers of economic growth (Hertz, Kusmin, Marre, \& Parker, 2014). If rural communities are to thrive, they must offer economic opportunities in terms of small businesses, entrepreneurship, and jobs. In some cases, activities such as agritourism events and festivals have fulfilled this need. Although agritourism cannot singularly create economic vitality, it can bolster a comprehensive approach to rural development (Leigh \& Blakely, 2016).

Research has shown that, over time, a high presence of independently owned, local businesses, and revenue generating community events statistically increases income and employment growth and decreases poverty rates in rural counties (Rupasingha \& Goetz, 2013). Whereas certain agritourism attractions in rural communities are available over an extended period of time, having time-limited events and festivals could encourage visitors to take advantage of additional cultural, social, and leisure activities (Pema \& Custodio, 2008). Events and experiences such as corn mazes and other seasonal agricultural venues can provide significant support for economic and community development in rural areas. These agritourism events attract visitors, 
offer community leadership opportunities, and garner financial and other social support from civic clubs and local organizations (Nickerson, Black, $\&$ McCool, 2016). In order to understand agritourism events and encourage more sustainable paths of economic development for resource-constrained rural communities, a deeper understanding of visitors' perceptions is necessary (Kastenholz \& Lima, 2011). However, there is limited existing knowledge concerning visitor's expectations for and satisfaction with agritourism events (Fortunato, 2014).

\section{Service Quality}

Service quality is the discrepancy between a consumer's expectation for service and his/her perception of service performance received (Zeithaml, Parasuraman, \& Malhotra, 2002). Since its emergence in the late 1970s, US and European schools of thought have made significant contributions to the comprehensive measurement of service quality. SERVQUAL, proposed by Parasuraman, Zeithaml, and Berry (1988), is a cornerstone of US service quality research. SERVQUAL is an instrument for measuring service quality attributes from five dimensions: reliability, responsiveness, assurance, empathy, and tangibles (e.g., physical facilities and equipment; Parasuraman et al., 1988). SERVQUAL highlighted the importance of interactions between consumers and front-line employees in addition to the tangible dimension (i.e., physical environment quality). However, the European viewpoint indicated that service quality should be evaluated from two general aspects: functional and technical. Functional quality refers to what a consumer receives in the service production and delivery process, while technical quality evaluates how well the outcome of the service satisfies a consumer's expectations (Gronroos, 1984).

Supporters of these two schools of thought have been vocal in debating shortcomings of the alternate approach. Buttle (1996) aligned with the European viewpoint and argued that SERVQUAL identifies functional quality by measuring the service process dimensions (i.e., interaction quality), but ignores the technical perspective (i.e., service outcome). Several scholars in the US pointed out that the European approach addresses intangible components, but ignores tangible components (i.e., physical environment quality; Bitner, 1990; Shostack, 1977). In order to synthesize the two conceptualizations and overcome the shortcomings of each approach, Brady and Cronin (2001) proposed the hierarchical service quality model (HSQM), which evaluates service quality with three dimensions: interaction quality, physical environment quality, and outcome quality.

\section{Hierarchical Service Quality Model (HSQM)}

Carman (1990) indicated that the assessment of service quality is a highly complicated procedure, which should be conducted at multiple levels of abstraction. Brady and Cronin (2001) further argued, "the missing link appears to be a unifying theory, or conceptualization, that reflects this complexity and the hierarchical nature of the construct" (p. 34). The hierarchical service quality model (HSQM) proposed by Brady and Cronin (2001), which evaluates service quality at three levels, represents a new perspective that effectively integrates the conceptualization of service quality.

The three levels of service quality for the HSQM are comprised of an overall level, a primary dimensional level, and a subdimensional level (Brady \& Cronin, 2001). The overall level captures a customer's general assessment of service quality. The primary dimensional level describes the major constructs that contribute to overall service quality: interaction quality, physical environment quality, and outcome quality. Brady and Cronin (2001) represented interaction quality using three subdimensions capturing visitor response to employee attitude, behavior, and expertise; physical environment quality was measured using three subdimensions of ambient conditions, design, and social factors; and outcome quality with three subdimensions of waiting time, tangibles, and valence. However, researchers using the HSQM framework (Brady \& Cronin, 2001) to study an array of tourism-related phenomena have selected different, context-specific subdimensions and measurement scales for the three primary dimensions, which capture visitors' experience of particular tourism options. For example, interaction quality was evaluated using conduct, expertise, and problem solving in an airline industry study (Wu \& Cheng, 2013), whereas security employee performance, 
food and beverage service, player interaction with spectators, and social environment were used in a sporting event study (Clemes, Brush et al., 2011). Physical environment quality was estimated based on equipment and ambient conditions in a travel industry study (Caro \& Garcia, 2008). Alternatively, store atmosphere, physical appeal, customer convenience, and social factors represented physical environment quality in a mobile communication services study (Clemes, Shu, \& Gan, 2013). Additionally, in a study on motels, outcome quality was assessed using pleasant stay, convenience, efficiency of check-out process, good sleep, and accuracy of billing (Clemes, Gan et al., 2011); order fulfillment, reliability, and emotional benefit variables were used to assess outcome quality of online shopping (M. Chen, Tsai, Hsu, \& Lee, 2013). The three dimensions of overall service quality (interaction quality, physical environment quality, and outcome quality) and their corresponding variables pertinent to tourism and hospitality contexts are discussed in detail below.

Interaction Quality. Interaction quality refers to the interpersonal interface between employees and consumers during service encounters (Lemke, Clark, \& Wilson, 2011). Brady and Cronin (2001) specifically examined the interactions between customers and service providers (e.g., employees, staff) in the process of service delivery. Accordingly, they divided the employee-customer interaction into three distinct employee aspects: attitude, behavior, and expertise. Brady and Cronin (2001) excluded customer-customer connection in the context of interaction quality, but measured it in terms of social factors, a subdimension of physical environment quality. However, the tourism industry is characterized by high-contact service. The cocreation of tourism experience integrates both employee-customer interface and customer-customer communication (Chathoth et al., 2014). Therefore, the present study tailored the HSQM and combined the subdimensions of measuring both employee-customer interaction and customer-customer interaction under the umbrella of interaction quality.

Physical Environment Quality. Physical environment quality describes the physical characteristics of a service experience from two primary perspectives: tangible and intangible (ambient) environment perspectives (Wakefield, Blodgett, \& Sloan, 1996). The tangible environment refers to the equipment and facilities involved in the service encounter (Thomas, 1978). The intangible (ambient) environment denotes the nonvisual aspects of the service process (e.g., temperature, music) at the site (Bitner, 1992). Accordingly, Caro and Garcia (2008) created two subdimensions for service environment quality in the travel industry: equipment and ambient conditions.

Outcome Quality. Outcome quality is the result of service actions and what a customer has received when the service delivery is complete (Gronroos, 1984). Outcome quality is thought to be a customer's summative view of the superiority of his or her service experience (Kang \& James, 2004). It has also been conceptualized as a collection of "experience properties" that are the outcome of service quality evaluated after the service encounter is complete (Woodside, Frey, \& Daly, 1989). As noted in the introduction, outcome quality measures predominately reflect assessments of the utilitarian or general affective nature of the experience. However, leisure is the main tourism motivator (Cetin \& Bilgihan, 2016), and nonutilitarian (i.e., hedonic/ experiential) aspects of tourism are essential to positive assessment and behavioral intentions toward tourism encounters (e.g., Cetin \& Bilgihan, 2016; S. Chen \& Lamberti, 2013; Stamboulis \& Skayannis, 2003). Therefore, it is logical to assume that items reflecting outcome quality perceptions of tourism-related service should emphasize hedonic/ experiential aspects.

Hedonic or experiential aspects have been conceptualized as sensory, emotional, and cognitive pleasure from and active engagement in consumer experiences (Holbrook \& Hirschman, 1982; Schmitt, 1999). These aspects are part of the tourist experience, and research confirms that tourists' expectations of a venue can be segmented by sensory, emotional, cognitive, and engagement experiences (Chen \& Lamberti, 2013). A tourist is said to be "physically, emotionally and intellectually involved in the experience" (Cetin \& Bilgihan, 2016, p. 139). Sensory pleasure entails pleasure from the five senses, such as enjoying the sights 
of the setting sun over a vineyard. Emotional pleasure reflects the positive affective feelings derived from the experience, such as the sense of calm from watching the setting sun. Cognitive pleasure includes positive experiences from learning and fantasies (Fiore, 2010; Holbrook \& Hirschman, 1982), such as learning about weather's impact on qualities of wine. Active engagement is seen as an important element of tourism and creative tourism, in particular, where the tourist's creative potential and skills are developed through active participation (Ali, Ryu, \& Hussain, 2016; Richard \& Wilson, 2006), such as capturing the sights of the vineyard in a photography class offered to tourists.

Sensory, emotional, and cognitive pleasure aspects along with engagement have been associated with positive evaluation of tourism products (e.g., Ali et al., 2016; Cetin \& Bilgihan, 2016; S. Chen \& Lamberti, 2013; Lee \& Beeler, 2009). Pine and Gilmore's experience economy 4E realms (educational, entertainment, escapist, and esthetic experiences) embody these aspects (Table 1). Moreover, this experience economy approach is seen as a vital component of a contemporary tourism industry (e.g., Council of Europe, 2015; Morgan, Elbe, \& Curiel, 2009; Williams, 2006). In support, research has illustrated the importance of the 4Es to positive evaluation of tourism products, such as bed and breakfasts (Oh, Fiore, \& Jeoung, 2007), sea cruises (Hosany \& Witham, 2010), wildlife watching (L.E. Anderson, Manning, Valliere, \& Hallo, 2010), festivals (Manthiou, Lee, Tang, \& Chiang, 2014; Mehmetoglu \& Engen, 2011), golf tournaments (Hwang \& Lyu, 2015), museums (Mehmetoglu \& Engen, 2011), creative tourism activities (Chang, 2013), rural markets (Fernades, Agapito, \& Mendes, 2015), and an array of other tourist activities (Jurowski, 2009). In particular, the 4Es have been useful in evaluating agritourism experiences in the form of wine tourism locations (Quadri-Felitti \& Fiore, 2013). Therefore, the 4Es may be appropriate for measuring outcome quality of agritourism events. The following section will address each of the 4E realms as potential subdimensions of overall service quality.

The 4Es as Subdimensional Contributors to Outcome Quality. According to Pine and Gilmore (1999), the 4Es are differentiated based on their positions within permeable quadrants formed by the intersection of two continua: active-passive involvement and absorption-immersion. As an example of the quadrants' permeable nature, "edutainment," such as a guided tour of a civil war reenactment, resides in two quadrants (i.e., educational and entertainment experiences). Active-passive involvement entails the person's level of active engagement in creating the experience. In entertainment and esthetic experiences, individuals do not directly contribute to or influence the source of the experience, whereas in educational and escapist experiences, individuals are integral to creating the experience due to cognitive exertion (e.g., mental processing, imagination) and/or physical engagement. Absorption, associated with entertainment and esthetic experiences, involves "occupying a person's attention by bringing the experience into the mind" (Pine \& Gilmore, 1999 , p. 31). Immersion, related to education and escapist experiences, involves "becoming physically or virtually a part of the experience itself" (Pine \& Gilmore, 1999, p. 31).

Table 1 provides (a) a description of each of the $4 \mathrm{E}$ quadrants or realms building on the work of Fiore, Niehm, Oh, Jeong, and Hausafus (2007), (b) relevant pleasure experiences for each realm according to Fiore et al. (2007), (c) potential activities creating the experience within agritourism, and (d) citations supporting the importance of the $4 \mathrm{E}$ realm and related pleasure experiences to positive evaluation of tourism experiences. For additional examples, Quadri-Felitti and Fiore (2012) provided a table encapsulating empirical literature supporting the importance of each of the 4E realms in one form of agritourism (wine tourism).

Therefore, based on conceptual and empirical support, the 4Es may be seen as subdimensions of outcome quality related to agritourism events. To summarize, outcome quality is conceptualized as a collection of "experience properties" evaluated after the service encounter is complete (Woodside et al., 1989). Given that hedonic experience from agritourism encounters is important to tourists (Sznajder et al., 2009) and the conceptual and empirical evidence (Quadri-Felitti \& Fiore, 2013; Thanh \& Kirova, 2018) for the 4Es as contributors to hedonic pleasure from agritourism encounters, it appears logical to posit that the 4Es are appropriate experience properties, which supports the 
relationship between the 4Es and outcome quality. Moreover, given empirical support for the significant relationship between the 4Es and overall perceived quality (Hosany \& Witham, 2010; Oh et al., 2007), the following hypothesis is proposed:

H1: The reconceptualized 4E-based HSQM model will explain the variance in overall perceived quality for agritourism events.

\section{Satisfaction}

The definition of satisfaction, as proposed by Oliver (1980), has been widely used by a number of scholars in the past three decades. Based on the expectation/disconfirmation paradigm, Oliver (1980) defined satisfaction as an emotional response to the perceived discrepancy between expectation before consumption and perceived performance after consumption. Similarly, Rust and Oliver (1994) described satisfaction as the extent to which an individual believes that some experience generates positive feelings. Fournier and Mick (1999) indicated that satisfaction is a summary psychological state resulting from a purchase or a sequence of consumer-product interactions. In the tourism and hospitality literature, the expectancydisconfirmation approach to satisfaction (e.g., Engel, Blackwell, \& Miniard, 1990; Oliver, 1980; Rust \& Oliver, 1994) has been the dominant paradigm to evaluate consumers' satisfaction in an array of contexts, including tourist shopping experiences (Yuksel \& Yuksel, 2007), vacation destinations (Tribe \& Snaith, 1998), hotels (W. Kim, Ma, \& Kim, 2006), and festivals and events (Lee, Kyle, \& Scott, 2012; Yuan \& Jang, 2008).

The Influence of Service Quality on Satisfaction. Service quality is a combination of overall service expectations and perceptions. These expectations result from customers' comparisons between their actual shopping experience and retailer service performance, and their prior expectations for shopping and services (Chau \& Kao, 2009; Dimitriadis \& Stevens, 2008; Leung \& To, 2001; Parasuraman, Zeithaml, \& Berry, 1985). Good quality retail service typically leads to customer satisfaction, which in turn has a positive impact on a customers' store loyalty (Carrillat, Jaramillo, \& Mulki, 2009; Gremler \& Gwinner, 2000; Hurst \& Niehm, 2012). Researchers have agreed that service quality is an antecedent to customer satisfaction in tourism studies (e.g., Lee, Graefe, \& Burns, 2004; TianCole \& Cromption, 2003). Particularly, Loureiro and Gonzalez (2008) addressed that unlike other service organizations that treat service quality as a technique for profit, service quality in tourism activities, especially agriculture/rural-based tourism, helps to define the excellence of visitors' recreation experience or satisfaction. Furthermore, the relationship between service quality and satisfaction has also been supported in HSQM studies (e.g., Clemes, Brush et al., 2011; Pollack, 2009).

In rural event and retail settings, image and quality are most frequently conveyed to both tourist and resident customers through service interactions while participating in an event or shopping. To this point, service interactions are also a significant means of customer relationship management. Rural tourism event operators and retailers need to deliver customer service that meets the expectations of both residents and tourists to create longterm customer satisfaction (Hurst \& Niehm, 2012). In order to achieve the objective of customer satisfaction, retailers and event operators must first know their target customers and understand how they choose and evaluate event and retail experiences. This is especially critical in rural tourism areas, because event and business operators serve a diverse customer group with differing expectations and perceptions for products and services. Satisfaction is ultimately determined by the customer (Hurst \& Niehm, 2012; Park, Lee, \& Park, 2011). Agritourism event operators that meet customerdefined service quality needs and expectations are more likely to create satisfaction for event participants, supporting the following hypothesis:

H2: Visitors' perceptions of 4E-based overall service quality will positively influence satisfaction with agritourism events.

\section{Revisit Intention}

Revisit intention is defined as an individual's predicted or planned future behavior to return to the venue (Oliver \& Swan, 1989). Warshaw and Davis 
(1985) described revisit intention as "the degree to which a person has formulated plans to perform or not perform some specified future behavior" ( $\mathrm{p}$. 214). It shows an individual's expectancy for a specific behavior or likelihood for action in a given setting (Fishbein \& Ajzen, 1975). Behavioral intention has been viewed as the most direct antecedent or predictor of behavior (Sheeran, 2002).

The Relationship Between Satisfaction and Revisit Intention. The relationship between satisfaction and revisit intention is supported by the theory of reasoned action, which suggests that an individual's intention for future behavior could be predicted by their attitudes toward the subject (Ajzen $\&$ Fishbein, 1980). In agritourism activities characterized by seasonal change, satisfactory experience is particularly important for marketers to attract repeat visitors (Choo \& Petrick, 2014). Assaker, Vinzi, and O'Connor (2011) examined the effect of novelty seeking, satisfaction, and destination image on tourists' return patterns. Findings from this fourcountry European study of 450 tourists showed that satisfaction had a significant and positive influence on immediate revisit intentions. Bigne, Sanchez, and Andreu (2009) addressed the role of variety seeking in short- and long-term revisit intentions in holiday destinations and found that in the long term, satisfaction was the strongest antecedent of a tourist's revisit intention. Similarly, Y. H. Kim, Kim, and Goh (2011) examined tourist behavior at a food event in the southwestern US. Their findings showed a significant and positive relationship between satisfaction and tourists' behavioral intention to revisit. As rural events provide recreational and social opportunities for both visitors and residents, maintaining existing and new stakeholder satisfaction is critical to building revisit intentions, supporting the next hypothesis:

H3: Visitors' satisfaction positively influences intention to revisit agritourism events.

\section{Method}

\section{Instrument}

The purpose of this study was to propose and test a modified HSQM framework by investigating the factors leading to revisit intention at agritourism events. Data were collected via a self-administered paper survey divided into five sections. The first section consisted of 18 items measuring visitors' educational, esthetic, entertainment, and escapist (i.e., the 4Es) experiences at the event, adapted from Oh et al. (2007). The second section included 9 items adapted from Ko, Zhang, Cattani, and Pastore (2011) and Wu and Cheng (2013), measuring perceptions of the ambient and tangible environment of the event, respectively. The third section of 14 items evaluated attendees' perceptions of interaction with other people (employees and other visitors) with scales adapted from Brady and Cronin (2001). The fourth section of 8 items examined attendees' overall satisfaction (Quadri-Felitti \& Fiore, 2013) and their revisit intention (Clemes, Gan et al., 2011). Items included in these four sections were measured on a 7-point Likert scale, anchored by $1=$ strongly disagree and $7=$ strongly agree. All measures had very good reported reliabilities with Cronbach's alphas or composite reliability estimates above 0.80 (Kline, 1998). The final section measured background information such as geographic, demographic, and socioeconomic characteristics, motivations for event attendance, trip characteristics, and travel behaviors.

\section{Pilot Testing}

Additional survey development was achieved through pilot testing. An electronic version of the survey was administered as a pilot test to 17 volunteer respondents. These volunteers watched a video of a visit to an agritourism venue, a lavender farm that offered tours and demonstrations. After viewing the video, respondents completed the survey and provided comments on its clarity and organization. Based on their comments, questions were rearranged and reworded, as were the instructions leading into the survey.

\section{Procedure}

Data were collected at three Iowa agritourism venues on two autumn weekends. The venues were farms, each with their own agritourism-focused events. One offered a pumpkin patch, a hay maze, and live animals; one featured a corn maze, a 
pumpkin patch, hayrides, scarecrow displays, and ponies; and the third had tours led by "living history" presenters discussing farm life in past centuries, wagon rides, and storytelling. Prior to data collection, research assistants were trained in data collection procedures and objectives, particularly in the intercept method in which potential respondents are approached by researchers at the location about which they will be asked. Weekends were chosen for data collection, as they were the timeframe expected to attract the most visitors to the events.

\section{Sample}

Pairs of research assistants were assigned a venue and collected data during the entirety of the venue's operating hours. They were stationed in pairs near the exits of each venue to intercept attendees as they completed the event. The research assistants approached every third individual or group as they were leaving to ask if they would complete the paper survey. Those who agreed and were older than 18 years of age were given a clipboard with the paper survey and a writing instrument. Only one survey was completed per group. By intercepting every third attendee or group of attendees, a systematic random sample was generated, limiting sampling bias (Huck, 2012).

\section{Data Analyses}

Descriptive statistics and data screening were performed in the statistics program R studio, 0.98.1091. Reliability of the data was assessed with Raykov's composite reliability (CR) estimates and validity was determined by comparing the intercorrelations between items with the square root of the average variance extracted (AVE) (Fornell \& Larcker, 1981). Structural equation modeling (SEM) in MPlus 1.2 was used to estimate the hypothesized model (Muthén \& Muthén, 2007). Following a twostep modeling process, the SEM model was first respecified as multiple confirmatory factor analysis measurement models. This step determines how well the measured variables define their latent constructs (Schumacker \& Lomax, 2010).

In the second step of the modeling process, the structural model was estimated (Kline, 1998). This step evaluates the fit of the overall model and the significance of the causal relationships between the latent variables. The models were estimated using Maximum Likelihood Estimation with Robust Standard Errors, as this estimation method does not require data to be normally distributed (Chou, Bentler, \& Satorra, 1991). Model fit was assessed with chi-square and other goodness-of-fit indices: CFI, TLI, RMSEA, and SRMR. Because chi-square is sensitive to nonnormality and large sample sizes (Schumacker \& Lomax, 2010), the ratio of chisquare to degrees of freedom was also considered, with a ratio of less than 3 indicating good fit (Hair, Black, Babin, \& Anderson, 2010). Cutoff values of CFI $>0.95$, TLI $>0.95$, RMSEA $<0.06$, SRMR $<0.08$ were established for the goodnessof-fit indices (Hu \& Bentler, 1999). Alternate models were assessed with the Satorra-Bentler scaled Chi-square difference test.

\section{Results}

A total of 583 questionnaires were collected. After the initial data screening, 529 surveys remained for analysis. Due to differences in event duration, $78.2 \%$ of the sample was collected at one venue. Visitor characteristics of the sample are summarized in Table 2. Approximately two thirds of respondents were female $(64.7 \%), 44$ years old or younger $(67.2 \%)$, and held an associate, bachelor, or graduate degree (65.4\%). More than half of respondents reported living in a household with an income below $\$ 100,000$ (57.9\%). In addition, the majority of respondents were white $(88.9 \%)$ and lived in Iowa $(76.7 \%)$.

\section{Measurement Model}

Initially, the fit of each latent construct in the hypothesized 4E-based HSQM model was evaluated. Factor loadings below 0.40 were removed to improve model fit (Hair et al., 2010). This resulted in the removal of Esthetic item 1 [I felt a real sense of harmony] and Esthetic item 3 [The experience was pretty bland (reversed coded)]. Additionally, the residual variance of the ambient factor was set to zero and three errors were allowed to correlate in order to improve model fit: education item 1 with education item 2, escapism item 1 with escapism item 2, 
Table 2

Agritourism Visitor Sample Characteristics $(N=529)$

\begin{tabular}{|c|c|}
\hline & $N(\%)$ \\
\hline \multicolumn{2}{|l|}{ Gender } \\
\hline Male & $169(31.9)$ \\
\hline Female & $342(64.7)$ \\
\hline Did not respond & $18(3.4)$ \\
\hline \multicolumn{2}{|l|}{ Age } \\
\hline $18-25$ & $79(14.9)$ \\
\hline $25-34$ & $133(25.1)$ \\
\hline $35-44$ & $144(27.2)$ \\
\hline $45-54$ & $70(13.2)$ \\
\hline $55-64$ & $44(8.3)$ \\
\hline $65-74$ & $26(4.9)$ \\
\hline Older than 75 & $2(0.4)$ \\
\hline Did not respond & $31(5.9)$ \\
\hline \multicolumn{2}{|l|}{ Ethnicity } \\
\hline White & $471(89.0)$ \\
\hline African American & $6(1.1)$ \\
\hline Asian & $7(1.3)$ \\
\hline Latino & $9(1.7)$ \\
\hline Native American & $6(1.1)$ \\
\hline Other & $1(0.2)$ \\
\hline Did not respond & $29(5.5)$ \\
\hline \multicolumn{2}{|l|}{ Household income } \\
\hline Less than $\$ 25,000$ & $56(10.3)$ \\
\hline$\$ 25,000-\$ 34,999$ & $49(9.3)$ \\
\hline$\$ 35,000-\$ 49,999$ & $66(12.5)$ \\
\hline$\$ 50,000-\$ 74,999$ & $69(13.0)$ \\
\hline$\$ 75,000-\$ 99,999$ & $66(12.5)$ \\
\hline$\$ 100,000-\$ 149,999$ & $82(15.5)$ \\
\hline$\$ 150,000-\$ 199,999$ & $30(5.7)$ \\
\hline Greater than $\$ 200,000$ & $28(5.3)$ \\
\hline Did not respond & $83(15.7)$ \\
\hline \multicolumn{2}{|l|}{ Location } \\
\hline Currently living in Iowa & $405(76.7)$ \\
\hline Currently living outside of Iowa & $24(4.5)$ \\
\hline Did not respond & $99(18.7)$ \\
\hline \multicolumn{2}{|l|}{ Education } \\
\hline High school or less & $147(27.8)$ \\
\hline Associate degree & $87(16.4)$ \\
\hline Bachelor's degree & $192(36.3)$ \\
\hline Graduate degree & $67(12.7)$ \\
\hline Other & $18(3.4)$ \\
\hline Did not respond & $18(3.4)$ \\
\hline
\end{tabular}

and social factors item 2 with social factors item 3 . The final HSQM model with 10 first-order factors, three second-order factors, and one third-order factor was evaluated and showed good fit to the data $\left[\chi^{2}(480)=962.93, p<0.00, \mathrm{CFI}=0.95, \mathrm{TLI}=0.95\right.$, RMSEA $=0.04$, SRMR $=0.06]$. Although the chisquare was significant, the ratio of chi-square to degrees of freedom of 2.01 was below the cutoff value of 3.00, supporting the fit of the model and providing evidence of the suitability of the hypothesized
4E-based HSQM model to explain the variance in overall service quality at agritourism events $(\mathrm{H} 1)$.

According to McDonald and Ho (2002), there may be more than one model that adequately fits a set of data. Therefore, several alternate models were tested and compared to the hypothesized model. The 4E-based HSQM model was a significantly better fit to the data than an oblique first order model $\left[\Delta \chi^{2}(181)=2663, p<0.000\right]$ and a model with a single second-order factor $\left[\Delta \chi^{2}(3)=971\right.$, $p<0.000]$. Orthogonal and bifactor models could not be identified mathematically. Thus, the reconceptualized 4E-based HSQM model was deemed the best fit for the data in further support of H1.

After confirming the fit of the hypothesized model, the full measurement model including the 4E-based HSQM model and the dependent variables of satisfaction and return intention was estimated and showed good fit to the data $\left[\chi^{2}(684)=1308.51\right.$, $p<0.00, \mathrm{CFI}=0.95, \mathrm{TLI}=0.95, \mathrm{RMSEA}=0.04$, $\mathrm{SRMR}=0.06]$. The measurement model also exhibited adequate reliability and validity. Composite reliability estimates (CR) (Raykov, 1997) were above 0.70 for all measures, with the exception of esthetics, indicating good reliability (Hair et al., 2010). Esthetics approached adequate reliability at 0.67 . The average variance extracted (AVE) for the constructs exceeded the cutoff value of 0.50 and the square root of the AVEs were greater than the intercorrelations between constructs thus establishing convergent and discriminant validity for all constructs but ambient and tangibles (Fornell \& Larcker, 1981). To further investigate the validity of the ambient and tangibles constructs, the factor loadings of the constructs were set to one and the measurement model was reassessed. The reassessed model had significantly poorer fit $\left[\Delta \chi^{2}(1)=16.42, p<0.000\right]$ in support of the discriminant validity of the ambient and tangibles factors (J. C. Anderson \& Gerbing, 1988). Standardized factor loadings, CR, and AVE values are reported in Table 3. Correlations between the first-order latent variables and the square root of the AVE values are reported in Table 4.

\section{Structural Model}

In the second stage of the modeling process, the structural model was estimated to test the predictive power of the reconceptualized 4E-based HSQM 
Table 3

Standardized Factor Loadings, Average Variance Extracted, and Composite Reliability for the Modified HSQM Measurement Model

\begin{tabular}{|c|c|c|c|}
\hline Factor/Items & $\begin{array}{l}\text { Standardized Factor } \\
\text { Loadings }\end{array}$ & AVE & CR \\
\hline Employee attitude & & 0.85 & 0.94 \\
\hline I can count on the employees being friendly. & 0.89 & & \\
\hline The employees' attitudes demonstrated their willingness to help me. & 0.95 & & \\
\hline The employees' attitudes showed me they understand my needs & 0.91 & & \\
\hline Employee behavior & & 0.83 & 0.94 \\
\hline The employees took actions to address my needs. & 0.92 & & \\
\hline The employees responded quickly to my needs. & 0.92 & & \\
\hline The behavior of the employees indicated to me that they understand my needs. & 0.90 & & \\
\hline Employee expertise & & 0.76 & 0.90 \\
\hline The employees knew their jobs. & 0.91 & & \\
\hline The employees were able to answer my questions quickly. & 0.86 & & \\
\hline The employees understood that I rely on their knowledge to meet my needs. & 0.84 & & \\
\hline Social factors & & 0.73 & 0.78 \\
\hline $\begin{array}{l}\text { I found that other customers consistently leave me with an impression that they } \\
\text { got good services. }\end{array}$ & 0.97 & & \\
\hline $\begin{array}{l}\text { Other customers did not affect the employees' ability to provide me with good } \\
\text { service. }\end{array}$ & 0.78 & & \\
\hline $\begin{array}{l}\text { The employees understood that other patrons affect my perception of their } \\
\text { services. }\end{array}$ & 0.81 & & \\
\hline Tangibles & & 0.70 & 0.90 \\
\hline The traffic flow at this event was understandable and predictable. & 0.75 & & \\
\hline I felt comfortable with the volume of sound/noise at this event. & 0.84 & & \\
\hline The layout of this event served my needs. & 0.89 & & \\
\hline The facility at this event was well designed. & 0.86 & & \\
\hline Ambient & & 0.66 & 0.85 \\
\hline The atmosphere at this event was excellent. & 0.89 & & \\
\hline The setting was what I am looking for in an agritourism event & 0.77 & & \\
\hline The facility was well maintained. & 0.77 & & \\
\hline Education & & 0.79 & 0.85 \\
\hline The experience has made me more knowledgeable. & 0.85 & & \\
\hline I learned a lot. & 0.87 & & \\
\hline The event experience stimulated my curiosity to learn new things. & 0.91 & & \\
\hline The event was a real learning experience. & 0.93 & & \\
\hline Esthetics & & 0.50 & 0.67 \\
\hline Just being here was very pleasant. & 0.67 & & \\
\hline The experience was very attractive. & 0.75 & & \\
\hline Entertainment & & 0.67 & 0.89 \\
\hline Activities of others were amusing to watch. & 0.75 & & \\
\hline I felt like I was living in a different time or place. & 0.64 & & \\
\hline I really enjoyed watching what others were doing. & 0.92 & & \\
\hline Activities of others were fun to watch. & 0.92 & & \\
\hline Escapism & & 0.66 & 0.85 \\
\hline I felt I played a different character here. & 0.70 & & \\
\hline I felt like I was living in a different time or place. & 0.86 & & \\
\hline The experience here let me imagine being someone else. & 0.90 & & \\
\hline I completely escaped from reality. & 0.77 & & \\
\hline Satisfaction & & 0.88 & 0.96 \\
\hline The overall experience of visiting the agritourism event made me feel: & & & \\
\hline Very dissatisfied-very satisfied. & 0.96 & & \\
\hline Very displeased-very pleased. & 0.96 & & \\
\hline Terrible-delighted. & 0.90 & & \\
\hline Revisit intention & & 0.82 & 0.93 \\
\hline I would recommend this event to a friend or colleague. & 0.96 & & \\
\hline I would consider this event as my first choice if I return to this area. & 0.95 & & \\
\hline I would return to this event if I were back in this area. & 0.80 & & \\
\hline
\end{tabular}


Table 4

Estimated Correlations Between First-Order Latent Variables for the Modified HSQM Model

\begin{tabular}{|c|c|c|c|c|c|c|c|c|c|c|c|c|}
\hline & 1 & 2 & 3 & 4 & 5 & 6 & 7 & 8 & 9 & 10 & 11 & 12 \\
\hline Employee attitude $^{1}$ & 0.92 & & & & & & & & & & & \\
\hline Employee behavior ${ }^{2}$ & 0.82 & 0.91 & & & & & & & & & & \\
\hline Employee expertise $^{3}$ & 0.88 & 0.88 & 0.87 & & & & & & & & & \\
\hline Social factors ${ }^{4}$ & 0.69 & 0.69 & 0.74 & 0.86 & & & & & & & & \\
\hline Tangibles $^{5}$ & 0.64 & 0.64 & 0.68 & 0.54 & 0.83 & & & & & & & \\
\hline Ambient $^{6}$ & 0.69 & 0.69 & 0.74 & 0.58 & 0.92 & 0.81 & & & & & & \\
\hline Education $^{7}$ & 0.36 & 0.36 & 0.39 & 0.30 & 0.38 & 0.42 & 0.89 & & & & & \\
\hline Esthetics $^{8}$ & 0.44 & 0.44 & 0.47 & 0.37 & 0.47 & 0.51 & 0.56 & 0.71 & & & & \\
\hline Entertainment ${ }^{9}$ & 0.38 & 0.39 & 0.41 & 0.33 & 0.41 & 0.45 & 0.49 & 0.60 & 0.82 & & & \\
\hline Escapism $^{10}$ & 0.26 & 0.26 & 0.28 & 0.22 & 0.28 & 0.31 & 0.34 & 0.41 & 0.37 & 0.81 & & \\
\hline Satisfaction $^{11}$ & 0.51 & 0.51 & 0.55 & 0.43 & 0.54 & 0.59 & 0.31 & 0.37 & 0.33 & 0.23 & 0.94 & \\
\hline Revisit intention $^{12}$ & 0.45 & 0.45 & 0.49 & 0.38 & 0.48 & 0.52 & 0.27 & 0.33 & 0.29 & 0.20 & 0.87 & 0.91 \\
\hline
\end{tabular}

Note. Numbers on the diagonal are the square root of the average variance extracted. Numbers on the off diagonal are correlation coefficients.

model (H2, H3). The structural model had good fit to the data $\left(\chi^{2}(685)=1306.23, p<0.00, \mathrm{CFI}=0.95\right.$, $\mathrm{TLI}=0.95, \mathrm{RMSEA}=0.04, \mathrm{SRMR}=0.06)$ and all parameter estimates, save one (ambient), were significant $(p<0.00)$. The chi-square was again significant, but the ratio of chi-square to degrees of freedom (1.91) was below the threshold of 3.00, indicating good model fit.

Hypothesis 2 proposed that visitor perception of the 4E-based overall service quality of the agritourism event would lead to visitor satisfaction. The structural model indicated that overall quality had a significant effect on satisfaction $\left(b^{*}=0.66\right.$, $z=11.96, p<0.00)$, thus hypothesis 2 was supported. The proposed 4E-based HSQM model explained $44 \%$ of the variance in satisfaction.

Subsequently, in hypothesis 3 , it was proposed that satisfaction with the agritourism event would significantly impact future revisit intentions. The effect of satisfaction on revisit intention was significant $\left(b^{*}=0.87, z=34.85, p<0.00\right)$, thus hypothesis 3 was also supported. The model explained $76 \%$ of the variance in revisit intention. Parameter estimates of the full structural model including the 4E-based HSQM model and the dependent variables of satisfaction and revisit intentions are reported in Figure 2.

\section{Conclusion and Implications}

The present study adds to the growing body of service quality literature by testing the applicability of a modified version of Brady and Cronin's (2001)
HSQM for assessing agritourism venues. Specifically, the revised 4E-based HSQM's interaction quality, physical environment quality, and outcome quality dimensions contributed to perceived overall service quality. Particularly noteworthy is the inaugural utilization of the 4Es scale developed by Oh et al. (2007) to measure outcome quality. Overall service quality was found to be an antecedent of visitor satisfaction, which consequently led to revisit intention towards agritourism events. These findings are consistent with the consumer satisfaction literature (Engel et al., 1990; Oliver, 1980; Rust \& Oliver, 1994) and the expectancy-disconfirmation paradigm (expectations-perceptions-satisfaction). It is also noteworthy to highlight several key findings from this study, where perceived overall service quality explained $44 \%$ of the variance in satisfaction with agritourism events and satisfaction in turn explained $76 \%$ of the variance in revisit intentions. This suggests that a moderate amount of variance in satisfaction was attributed to visitors' perceived overall service quality (including outcome quality and the 4-Es) at the agritourism event and a substantial amount of variance in their revisit intentions was due to their overall event satisfaction. These results further support the revised 4E-based HSQM model and its ability to predict satisfaction and revisit intentions.

The modified HSQM tested in the present study effectively combined the traditional service quality aspects of SERVQUAL and the experiential marketing aspects of the 4Es. As Pine and Gilmore (1999) 


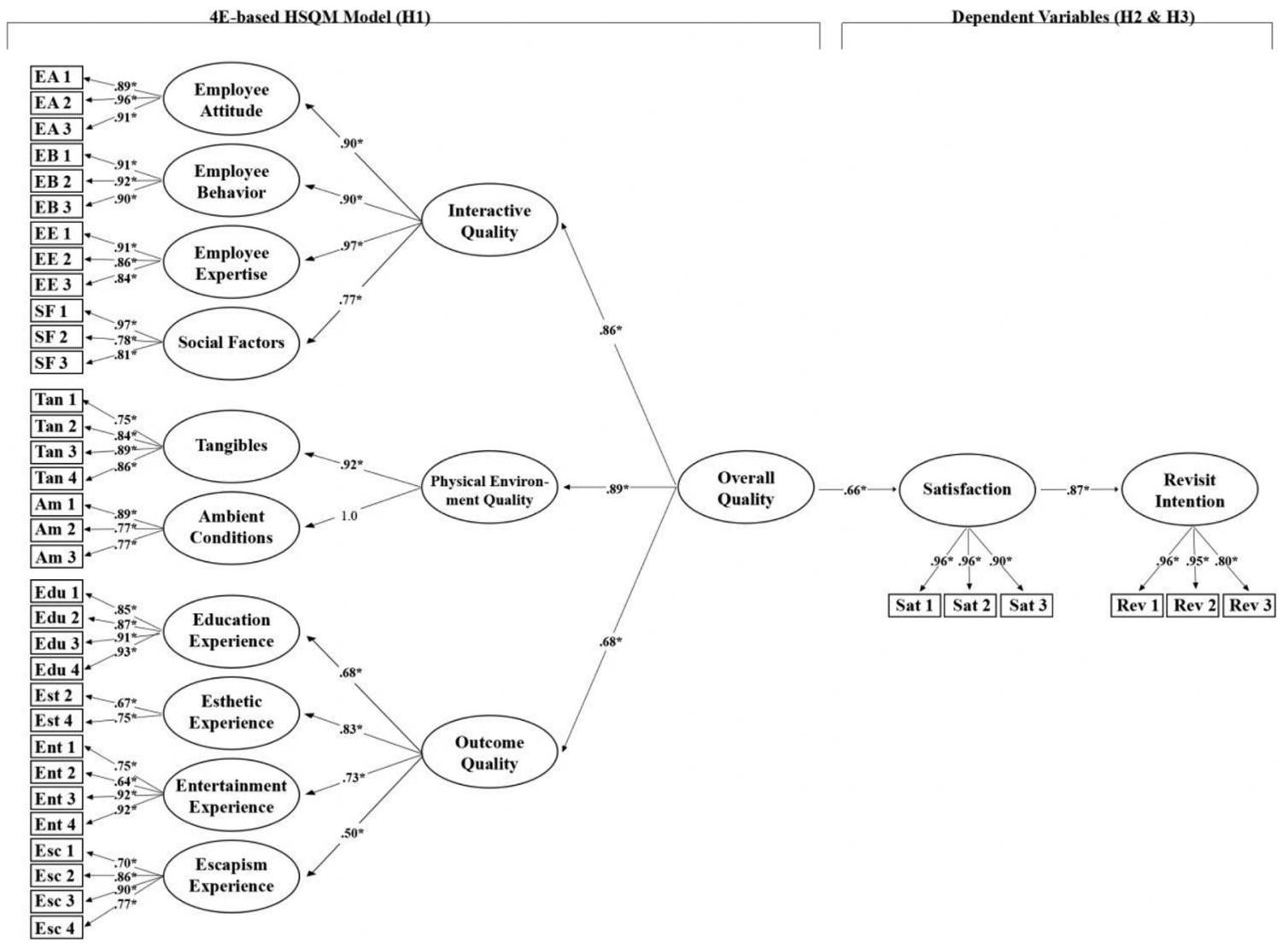

Figure 2. Parameter estimates of the reconceptualized 4E-based HSQM structural model and dependent variables. ${ }^{*} p<0.00$.

indicated, "many companies today wrap experiences around their existing goods and services to differentiate their offerings" (p. 15). This suggests that the traditional assessment paradigm of service quality may be incomplete and deficient in explaining customer value from service encounters, and this may be particularly true for the experience-rich nature of tourism experiences (Quadri-Felitti \& Fiore, 2012). Service in the tourism and hospitality industry could become a more attractive offering by embracing experience-staging techniques (Gilmore $\&$ Pine, 2002).

Results of the present study illustrate that among the three overall service quality dimensions for agritourism events, physical environment quality was the dominant contributor, followed by interaction quality and outcome quality, respectively (see Fig. 2). Moreover, it should be noted that the relative weighting among the three HSQM dimensions of overall service quality in the present study differ from a number of previous studies (e.g., Clemes, Brush et al., 2011; Clemes, Gan et al., 2011). Together these findings contribute to the body of extant tourism and event management literature and support inclusion of the 4Es as a plausible replacement construct for outcome quality in the original HSQM framework (Brady \& Cronin, 2001), as applied to agritourism events.

Similar to previous studies, this research utilized revised measurement scales tailored to agritourism events. The relative weighting among the three HSQM dimensions of overall service quality depends heavily on the salience of service offerings in different industry sectors. For example, Caro and Garcia (2008) indicated that overall service quality for travel agencies was manifested by outcome quality and interaction quality, whereas physical environment quality had less of a role 
to play. Conversely, all three dimensions contributed equally to overall service quality in the context of mobile communication services (Clemes et al., 2013).

Physical environment quality contributed the most to overall service quality in this study. As suggested by items in the respective measurement scales, these results indicate that event planners would be well advised to improve the environment at agritourism event sites from both intangible (e.g., atmosphere) and tangible (e.g., facilities) perspectives to satisfy the target customer. For instance, it appears that enhancing the cleanliness, orderliness, and attractiveness of the agritourism event setting may do the most to increase visitors' overall quality perceptions.

Interaction quality also played an important role in overall service quality. Among the four subdimensions of interaction quality, the three factors related to employee performance were more important than the social factor. Superior service at agritourism events may be delivered through well-trained and professional employees who not only have background knowledge of an event and the local community (e.g., history, culture, tourism-related information), but also possess the professional attitudes and behaviors required in the service industry. In particular, frontline staff need to understand the "dos" and "don'ts" of interactions with customers (e.g., procedures for dealing with problems, responding to customer complaints). Social factors, which entails the contact among customers, was the least important indicator in measuring customers' perceptions of interactive quality. At many agritourism events in rural communities, visitors are composed of both local residents and tourists. Service providers should strive to design activities and programs that increase interaction among local residents and tourists. Local residents serve as effective information sources for tourists and thus interactions with local residents can enrich the tourist experience (Hurst \& Niehm, 2012).

Results of the study indicated that, although outcome quality played a lesser role (than physical environment quality and interaction quality) in the assessment of overall service quality, it nonetheless had a significant impact. All of the four experience (4E) dimensions were found to contribute significantly to outcome quality. Although contrary to past 4E studies in tourism settings (e.g., Hosany \& Witham, 2010; Oh et al., 2007; Quadri-Felitti \& Fiore, 2013), the present findings support Pine and Gilmore's (1998) contention that customers gain the most gratifying experience when all four experience dimensions occur to hit the "sweet spot." As noted above, the esthetic experience dimension was the strongest contributor to outcome quality for agritourism events. It was followed by entertainment, educational, and escapist experience dimensions, respectively. Event planners may be well advised to allocate their limited human and financial resources based on the different weights of these four dimensions.

From a practitioner perspective, the results of the present study indicate an innovative approach for event planners to conceptualize and implement service quality. In particular, experience design and orchestration can be considered an increasingly critical component of the service delivery system at agritourism events. Practitioners who move beyond quality excellence to the design and provision of memorable experiences will create additional value in agritourism events. By better understanding how customers value their trip experiences to agritourism events, tourism and event managers could develop marketing strategies and service delivery tailored to their customers' specific needs.

Based on results of the present study, it is also recommended that each of the four experience dimensions be demonstrated in diverse activities (see Table 1 for sample activities) and marketing programs. For example, the appealing pastoral scenery at agritourism events could be highlighted in pictorial form in social media campaigns, advertising, travel brochures, and other promotional materials, as it is eye catching for potential tourists who pursue esthetic experiences. Furthermore, offering special activities such as wine tastings, home winemaking seminars, and wine-related craft classes at a wine festival can synthesize entertainment and educational components, because they provide visitors with both fun and informative aspects of event experience, known as "edutainment" (Pine \& Gilmore, 1999). Escapist experiences are more immersive and active, where attendees deeply engage in a different time or place, instead of passively visit an event. A good example would be farm scavenger hunts for children. 


\section{Limitations and Future Research}

There are several limitations to this study that should be addressed in future research. First, given the data were collected at three agritourism events in the state of Iowa in the US, generalizability of the research model to all agritourism venues would be uncertain. Future studies could further test the model at various types of agritourism events in other regions or countries. Second, our research primarily analyzed customers' perceptions of service quality. Future research could evaluate service quality from the perspective of service providers at agritourism events in order to increase customers' satisfaction. Third, this study examined customers' immediate perceptions of service quality at agritourism event sites. A longitudinal study conducted during a certain period of time after the event may provide more information about the impact of customers' perceptions of service quality on their satisfaction and future behavioral intentions. Fourth, future research could compare the modified HSQM proposed in this study against other alternative models (e.g., SERVPERF) in order to provide greater theoretical clarity about how service quality influences customers' attitudes and behaviors. Finally, the present study examined revisit intention as a consequential construct in the theoretical model. Future studies could evaluate word of mouth and revisit behaviors in order to more precisely determine the consequential impact of service quality.

\section{References}

Ajzen, I., \& Fishbein, M. (1980). Understanding attitudes and predicting social behavior. Englewood Cliffs, NJ: Prentice-Hall.

Ali, F., Ryu, K., \& Hussain, K. (2016). Influence of experiences on memories, satisfaction and behavioral intentions: A study of creative tourism. Journal of Travel \& Tourism Marketing, 33(1), 85-100.

Anderson, J. C., \& Gerbing, D. W. (1988). Structural equation modeling in practice: A review and recommended two-step approach. Psychological Bulletin, 103(3), $411-423$

Anderson, L. E., Manning, R. E., Valliere, W. A., \& Hallo, J. C. (2010). Normative standards for wildlife viewing in parks and protected areas. Human Dimensions of Wildlife: An International Journal, 15(1), 1-15.

Assaker, G., Vinzi, V. E., \& O'Connor, P. (2011). Examining the effect of novelty seeking satisfaction, and destination image on tourists' return pattern: A two factor, non-linear latent growth model. Tourism Management, 32(4), 890-901.

Barbieri, C., \& Mshenga, P. M. (2008). The role of the firm and owner characteristics on the performance of agritourism farms. Sociologia Ruralis, 48, 166-183.

Bigne, J. E., Sanchez, I., \& Andreu, L. (2009). The role of variety seeking in short and long run revisit intentions in holiday destinations. International Journal of Culture, Tourism, and Hospitality Research, 3(2), 103-115.

Bitner, M. J. (1990). Evaluating service encounters: The effects of physical surroundings and employee responses. Journal of Marketing, 54(2), 69-82.

Bitner, M. J. (1992). Servicescapes: The impact of physical surroundings on customers and employees. Journal of Marketing, 56(2), 57-71.

Bolton, R. N., \& Drew, J. H. (1991). A multistage model of customers' assessments of service quality and value. Journal of Consumer Research, 17(4), 375-384.

Brady, M. K., \& Cronin Jr., J. J. (2001). Some new thoughts on conceptualizing perceived service quality: A hierarchical approach. Journal of Marketing, 65(3), 34-49.

Brown, D. L., \& Schafft, K. A. (2011). Rural people and communities in the 21st century: Resilience and transformation. Cambridge, UK: Polity Press.

Buttle, F. (1996). SERVQUAL: Review, critique, research agenda. European Journal of Marketing, 30(1), 8-32.

Carman, J. M. (1990). Consumer perceptions of service quality: An assessment of the SERVQUAL dimensions. Journal of Retailing, 66(1), 33-55.

Caro, L., \& Garcia, J. (2008). Developing a multidimensional and hierarchical service quality for the travel agency industry. Tourism Management, 29(4), 706-720.

Carrillat, F. A., Jaramillo, F., \& Mulki, J. P. (2009). Examining the impact of service quality: A meta-analysis of empirical evidence. Journal of Marketing Theory and Practice 17(2), 95-110.

Cetin, G., \& Bilgihan, A. (2016). Components of cultural tourists' experiences in destinations. Current Issues in Tourism, 19(2), 137-154

Chang, L. (2013). Influencing factors on creative tourists revisiting intentions: The roles of motivation, experience and perceived value (doctoral dissertation). Clemson University. Retrieved from http://tigerprints.clemson.edu/cgi/ viewcontent.cgi? article $=2084 \&$ context $=$ all dissertations

Chathoth, P. K., Ungson, G. R., Altinay, L., Chan, E. S. W., Harrington, R., \& Okumus, F. (2014). Barriers affecting organizational adoption of higher order customer engagement in tourism service interactions. Tourism Management, 42, 181-193.

Chau, V. S., \& Kao, Y. (2009). Bridge over troubled water or long and winding road? Gap-5 in airline service quality performance measures. Managing Service Quality: An International Journal, 19(1), 106-134.

Chen, M., Tsai, K., Hsu, Y., \& Lee, K. (2013). E-service quality impact on online customer's perceived value and loyalty. China-USA Business Review, 12(5), 473-485.

Chen, S., \& Lamberti, L. (2013). Segmenting Chinese tourists by the expected experience at theme parks. 
International Journal of Engineering Business Management, 5(22), 1-9.

Chhabra, D., Sills, E., \& Cubbage, F. W. (2003). The significance of festivals to rural economics: Estimating the economic impact of Scottish Highland Games in North Carolina. Journal of Travel Research, 41(4), 421-427.

Choo, H., \& Petrick, J. F. (2014). Social interactions and intentions to revisit for agritourism service encounters. Tourism Management, 40, 372-381.

Chou, C.-P., Bentler, P. M., \& Satorra, A. (1991). Scaled test statistics and robust standard errors for non-normal data in covariance structure analysis: A Monte Carlo study. British Journal of Mathematical and Statistical Psychology, 44(2), 347-357.

Clemes, M. D., Brush, G. J., \& Collins, M. J. (2011). Analysing the professional sport experience: A hierarchical approach. Sport Management Review, 14(4), 370-388.

Clemes, M. D., Gan, C., \& Ren, M. (2011). Synthesizing the effects of service quality, value, and customer satisfaction on behavioral intentions in the motel industry: An empirical analysis. Journal of Hospitality \& Tourism Research, 35(4), 530-568.

Clemes, M. D., Shu, X., \& Gan, C. (2013). Mobile communications: A comprehensive hierarchical modeling approach. Asia Pacific Journal of Marketing and Logistics, 26(1), 114-146.

Council of Europe. (2015). Cultural routes management: From theory to practice. Strasbourg, France: Council of Europe Publishing.

Dagger, T. S., \& Sweeney, J. C. (2007). Service quality attribute weights: How do novice and longer-term customers construct service quality performance? Journal of Service Research, 10, 22-42.

Dimitriadis, S., \& Stevens, E. (2008). Integrated customer relationship management for service activities: An internal/external gap model. Managing Service Quality: An International Journal, 18(5), 496-511.

Engel, J. F., Blackwell, R. D., \& Miniard, P. W. (1990). Consumer behavior (6th ed.). Chicago, IL: The Dryden Press.

Fernades, S., Agapito, D., \& Mendes, J. (2015). The revisitalization of the Querença market: Exploring the visitor experience. Journal of Spatial and Organizational Dynamics, III(3), 216-226.

Fiore, A. M. (2010). Understanding aesthetics for the merchandising and design professional. New York, NY: Fairchild.

Fiore, A. M., Niehm, L., Oh, H., Jeong, M., \& Hausafus, C. (2007). Experience economy strategies: Adding value to small rural businesses. Journal of Extension, 45(2). Retrieved from https://www.joe.org/joe/2007april/iw4.php

Fishbein, M., \& Ajzen, I. (1975). Belief, attitude, intention and behavior: An introduction to theory and research. Reading, MA: Addison-Wesley.

Flora, C. B. (2018). Rural communities: Legacy + change. Abingdon, UK: Routledge.

Fornell, C., \& Larcker, D. F. (1981). Evaluating structural equation models with unobservable variables and measurement error. Journal of Marketing Research, 18, 39-50.

Fortunato, M. W. P. (2014). Supporting rural entrepreneurship: A review of conceptual developments from research to practice. Community Development, 45, 387-408.

Fournier, S., \& Mick, D. G. (1999). Rediscovering satisfaction. Journal of Marketing, 63(4), 5-23.

Gilmore, J. H., \& Pine, J. B. (2002). Differentiating hospitality operations via experiences. Why selling services is not enough. Cornell Hotel and Restaurant Administration Quarterly, 43(3), 87-96.

Govindasamy, R., \& Kelley, K. (2014). Agritourism consumers' participation in wine tasting events an econometric analysis. International Journal of Wine Business Research, 26(2), 120-138.

Gremler, D. D., \& Gwinner, K. P. (2000). Customeremployee rapport in service relationships. Journal of Service Research, 3(1), 82-104.

Gronroos, C. (1984). A service quality model and its marketing implications. European Journal of Marketing, 18(4), 36- 44.

Hair Jr., J. F., Black, W. C., Babin, B. J., \& Anderson, R. E. (2010). Multivariate data analysis: A global perspective (7th ed.). Hoboken, NJ: Pearson Education.

Hertz, T., Kusmin, L., Marre, A., \& Parker, T. (2014). Rural employment trends in recession and recovery. Washington, DC: USDA Economic Research Service, Economics Research Report 172.

Holbrook, M. B., \& Hirschman, E. C. (1982). The experiential aspects of consumption: Consumer fantasies, feelings, and fun. Journal of Consumer Research, 9(2), 132-140.

Hosany, S., \& Witham, M. (2010). Dimensions of cruisers' experiences, satisfaction, and intention to recommend. Journal of Travel Research, 49(3), 351-364.

Hu, L.-T., \& Bentler, P. M. (1999). Cutoff criteria for fit indexes in covariance structure analysis: Conventional criteria versus new alternatives. Structural Equation Modeling: A Multidisciplinary Journal, 6, 1-55.

Huck, S. W. (2012). Reading statistics and research (6th ed.). Boston, MA: Pearson.

Hurst, J. L., \& Niehm, L. S. (2012). Tourism shopping in rural markets: A case study in rural Iowa. International Journal of Culture Tourism and Hospitality Research, 6(3), 194-208.

Hwang, J., \& Lyu, S. O. (2015). The antecedents and consequences of well-being perception: An application of the experience economy to golf tournament tourists. Journal of Destination Marketing \& Management, 4(4), 248-257.

Jurowski, C. (2009). An examination of the four realms of tourism experience theory. Proceedings of the International Council on Hotel, Restaurant, and Institutional Education, USA. Retrieved from https://scholarworks. umass.edu/refereed/Sessions/Wednesday/23/

Kang, G., \& James, J. (2004). Service quality dimensions: An examination of Gronroos's service quality model. Managing Service Quality, 14(4), 266-277. 
Kastenholz, E., \& Lima, J. (2011). The integral rural tourism experience from the tourist's point of view: A qualitative analysis of its nature and meaning. Tourism \& Management Studies, 7, 62-74.

Kim, W., Ma, X., \& Kim, D. (2006). Determinants of Chinese hotel customers' e-satisfaction and purchase intentions. Tourism Management, 27(5), 890-900.

Kim, Y. H., Kim, M., \& Goh, B. K. (2011). An examination of food tourist's behavior: Using the modified theory of reasoned action. Tourism Management, 32(5), 1159-1165.

Kline, R. B. (1998). Principles and practice of structural equation modeling. New York, NY: Guilford Press.

Ko, Y. J., \& Pastore, D. L. (2004). Current issues and conceptualizations of service quality in the recreational sport industry. Sport Marketing Quarterly, 13(3), 159-167.

Ko, Y., Zhang, J., Cattani, K., \& Pastore, D. (2011). Assessment of event quality in major spectator sports. Managing Service Quality, 21(3), 304-322.

Kuehn, D., Hilchey, D., Ververs, D., Dunn, K. L., \& Lehman, P. (1998). Considerations for agritourism development. Sea Grant New York, Cornell University, State University of New York.

Lee, J., \& Beeler, C. (2009). An investigation of predictors of satisfaction and future intentions: Links to motivations, involvement, and service quality in a local festival. Event Management, 13(1), 17-29.

Lee, J., Graefe, A. R., \& Burns, R. C. (2004). Service quality, satisfaction, and behavioral intention among forest visitors. Journal of Travel \& Tourism Marketing, 17(1), 73-82.

Lee, J., Kyle, G., \& Scott, D. (2012). The mediating effect of place attachment on the relationship between festival satisfaction and loyalty to the festival hosting destination. Journal of Travel Research, 51(6), 754-767.

Leigh, N. G., \& Blakely, E. J. (2016). Planning local economic development: Theory and practice. Thousand Oaks, CA: SAGE publications.

Lemke, F., Clark, M., \& Wilson, J. (2011). Customer experience quality: An exploration in business and consumer contexts using repertory grid technique. Journal of the Academy of Marketing Science, 39(6), 846-869.

Leung, C., \& To, C. K. (2001). Measuring perceived service quality of fashion stores: A test-retest reliability investigation. Journal of Fashion Marketing Management: An International Journal, 5(4), 324-329.

Loureiro, S. M. C., \& Gonzalez, F. J. M. (2008). The importance of quality, satisfaction, trust, and image in relation to rural tourist loyalty. Journal of Travel \& Tourism Marketing, 25(2), 117-136.

Lu, Y., Zhang, L., \& Wang, B. (2009). A multidimensional and hierarchical model of mobile service quality. Electronic Commerce Research and Applications, 8(5), 228-240.

Manthiou, A., Lee, S., Tang, L., \& Chiang, L. (2014). The experience economy approach to festival marketing: Vivid memory and attendee loyalty. Journal of Service Marketing, 28(1), 22-35.

Marques, H. (2006). Searching for complementarities between agriculture and tourism - the demarcated wine- producing regions of northern Portugal. Tourism Economics, 12, 147-155.

Martinez, J. A., Ko, Y. J., \& Martinez, L. (2010). An application of fuzzy logic to service quality research: A case of fitness service. Journal of Sport Management, 24(5), 502-523.

McDonald, R. P., \& Ho, M. R. (2002). Principles and practice in reporting structural equation analyses. Psychological Methods, 7(1), 64-82.

Mehmetoglu, M., \& Engen, M. (2011). Pine and Gilmore's concept of experience economy and its dimensions: An empirical examination in tourism. Journal of Quality Assurance in Hospitality \& Tourism, 12(4), 237-255.

Morgan, M., Elbe, J., \& Curiel, J. (2009). Has the experience economy arrived? The views of destination managers in three visitor-dependent areas. The International Journal of Tourism Research, 11(2), 201-218.

Muthén, L. K., \& Muthén, B. O. (2007). Mplus user's guide (6th ed.). Los Angeles, CA: Muthén \& Muthén.

Nickerson, N. P., Black, R. J., \& McCool, S. F. (2011). Agritourism: Motivations behind farm/ranch business diversification. Journal of Travel Research, 40(1), 19-26.

Niehm, L. S., Fitzgerald, M., \& Muske, G. (2017). Family business contributions to sustainable and entrepreneurial rural communities over time. Research webinar presented in coordination with the North Central Center for Rural Development (NCRCRD), July 20.

Oh, H., Fiore, A., \& Jeoung, A. (2007). Measuring experience economy concepts: Tourism applications. Journal of Travel Research, 46(2), 119-132.

Oliver, R. L. (1980). A cognitive model of the antecedents and consequences of satisfaction decisions. Journal of Marketing Research, 17(4), 460-469.

Oliver, R. L., \& Swan, J. E. (1989). Equity and disconfirmation perceptions as influences on merchant and product satisfaction. Journal of Consumer Research, 16(3), 372-383.

Oppermann, M. (1997). First-time and repeat visitors to New Zealand. Tourism Management, 18(3), 177-181.

Parasuraman, A., Zeithaml, V. A., \& Berry, L. L. (1985). A conceptual model of service quality and its implications for future research. Journal of Marketing, 49(4), 41-50.

Parasuraman, A., Zeithaml, V. A., \& Berry, L. L. (1988). SERVQUAL: A multiple-item scale for measuring consumer perceptions of service quality. Journal of Retailing, 64(1), 12-40.

Park, J., Lee, G., \& Park, M. (2011). Service quality dimensions perceived by film festival visitors. Event Management, 15(1), 49-61.

Pema, F., \& Custodio, M. J. (2008). Importance of events in tourism: Impacts of the UEFA-EURO 2004 on the accommodation industry in Algarve, Portugal. Anatolia, 19(1), 5-22.

Pine, J. B., \& Gilmore, J. H. (1998). Welcome to the experience economy. Harvard Business Review, 76(4), 96-105.

Pine, J. B., \& Gilmore, J. H. (1999). The experience economy: Work is a theatre and every business a stage. Boston, MA: Harvard Business School Press. 
Pollack, B. (2009). Linking the hierarchical service quality model to customer satisfaction and loyalty. Journal of Service Marketing, 23(1), 42-50.

Quadri-Felitti, D., \& Fiore, A. (2012). Experience economy constructs as a framework for understanding wine tourism. Journal of Vacation Marketing, 18(1), 3-15.

Quadri-Felitti, D., \& Fiore, A. (2013). Destination loyalty: Effects of wine tourists' experiences, memories, and satisfaction on intentions. Tourism and Hospitality Research, 13(1), 47-62.

Ramu, G., \& Kathleen, K. (2014) Agritourism consumers' participation in wine tasting events: An econometric analysis. International Journal of Wine Business Research, 26(2), 120-138.

Raykov, T. (1997). Estimation of composite reliability for congeneric measures. Applied Psychological Measurement, 21(2), 173-184.

Reid, S. (2011). Event stakeholder management: Developing sustainable rural event practices. International Journal of Event and Festival Management, 2(1), 20-36.

Richards, G., \& Wilson, J. (2006). Developing creativity in tourist experiences: A solution to the serial reproduction of culture? Tourism Management, 27(6), 1209-1223.

Rupasingha, A., \& Goetz, S. J. (2013). Self-employment and local economic performance: Evidence from US counties. Papers in Regional Science, 92(1), 141-161.

Rust, R. T., \& Oliver, R. L. (1994). Service quality: Insights and managerial implication from the frontier. In R. T. Rust \& R. L. Oliver (Eds.), Service quality: New directions in theory and practice (pp. 1-19). Thousand Oaks, CA: Sage.

Schmitt, B. H. (1999). Experiential marketing: How to get customers to sense, feel, think, act, relate to your company and brands. New York, NY: The Free Press.

Schumacker, R. E., \& Lomax, R. G. (2010). A beginner's guide to structural equation modeling (3rd ed.). New York, NY: Routledge.

Sheeran, P. (2002). Intention-behavior relations: A conceptual and empirical review. European Review of Social Psychology, 12(1), 1-36.

Shonk, D. J., \& Chelladurai, P. (2008). Service quality, satisfaction, and intent to return in event sport tourism. Journal of Sport Management, 22(5), 587-602.

Shostack, L. G. (1977). Breaking free from product marketing. Journal of Marketing, 41(2), 73-80.

Stamboulis, Y., \& Skayannis, P. (2003). Innovation strategies and technology for experience-based tourism. Tourism Management, 24(1), 35-43.
Sznajder, M., Przezborska, L., \& Scrimgeour, F. (2009). Agritourism. Wallingford, UK: CABI.

Thanh, T. V., \& Kirova, V. (2018). Wine tourism experience: A netnography study. Journal of Business Research, 83, $30-37$.

Thomas, D. R. E. (1978). Strategy is different in service businesses. Harvard Business Review, 56, 158-164.

Tian-Cole, S., \& Cromption, J. (2003). A conceptualization of the relationships between service quality and visitor satisfaction, and their links to destination selection. Leisure Studies, 22(1), 65-80.

Tribe, J., \& Snaith, T. (1998). From SERVQUAL to HOLSAT: Holiday satisfaction in Varadero, Cuba. Tourism Management, 19(1), 25-34.

Wakefield, K. L., Blodgett, J. G., \& Sloan, H. J. (1996). Measurement and management of the sportscape. Journal of Sports Management, 10, 15-31.

Warshaw, P., \& Davis, F. (1985). Disentangling behavioral intention and behavioral expectation. Journal of Experimental Social Psychology, 21(3), 213-228.

Wicks, B. E., \& Fesenmaier, D. R. (1993). A comparison of visitor and vendor perceptions of service quality at a special event. Festival Management \& Event Tourism, 1(1), 19-26.

Williams, A. (2006). Tourism and hospitality marketing: Fantasy, feeling and fun. International Journal of Contemporary Hospitality Management, 18(6), 482-495.

Woodside, A. G., Frey, L. L., \& Daly, R. (1989). Linking service quality, customer satisfaction, and behavioral intention. Journal of Health Care Marketing, 9(4), 5-17.

Wu, H., \& Cheng, C. (2013). A hierarchical model of service quality in the airline industry. Journal of Hospitality and Tourism Management, 20, 13-22.

Yuan, J., \& Jang, S. (2008). The effects of quality and satisfaction on awareness and behavioral intentions: Exploring the role of a wine festival. Journal of Travel Research, 46(3), 279-288.

Yuksel, A., \& Yuksel, F. (2007). Shopping risk perceptions: Effects on tourists' emotions, satisfaction and expressed loyalty intentions. Tourism Management, 28(3), 703-713.

Zeithaml, V. A., Berry, L. L., \& Parasuraman, A. (1996). The behavioral consequences of service quality. Journal of Marketing, 60(2), 31-46.

Zeithaml, V. A., Parasuraman, A., \& Malhotra, A. (2002). Service quality delivery through web sites: A critical review of extant knowledge. Journal of the Academy of Marketing Science, 30(4), 362-375. 
Copyright of Event Management is the property of Cognizant, LLC and its content may not be copied or emailed to multiple sites or posted to a listserv without the copyright holder's express written permission. However, users may print, download, or email articles for individual use. 